How to Cite

Sylvester, O., \& Ade, O. S. (2018). Revenue allocation in Nigeria: implications for sustainable national

development. International Journal of Social Sciences, 1(1), 31-41. https://doi.org/10.31295/ijss.v1n1.15

\title{
Revenue Allocation in Nigeria: Implications for Sustainable National Development
}

\author{
Ohiomu Sylvester \\ Edo University, Iyamho, Edo State, Nigeria \\ Corresponding author email: ohmsylve@yahoo.com \\ Oluyemi Sunday Ade \\ Nigerian Deposit Insurance Corporation, Benin City, Nigeria
}

\begin{abstract}
This study examines the structure and formula for revenue allocation in Nigeria and highlights its implications for sustainable national development. The work uses the methodology of Error correction model (ECM) in conjunction with diagnostic tests of variables using Johansen Co-integration tests for robust policy recommendations. Using the Gross Domestic Product (GDP) as the dependent variable and Revenue allocation to the three levels of government, inflation, and lending interest rate as the independent variables, the results from the study show that revenue allocations and the other variables have a significant relationship with economic growth in Nigeria. Based on our findings, the study recommends among others that there should be accountability and transparency in the federating units to achieve national goals and objectives. Various levels of government should be given adequate funds to enable it to carry out its expenditure responsibilities to accelerate grass root development in the economy. The government should focus on optimal revenue allocation targeted at economic growth to improve the standard of living of the citizenry. These would aid to achieve the goals of desired economic growth and sustainable national development in the years ahead.

Keywords---error correction model, federalism, fiscal discipline, optimal growth, revenue formula.
\end{abstract}

\section{Introduction}

The size of revenue that government generates at any point in time is influenced by its resource endowment, level of economic activities and the efficiency of its revenue collection machinery. The stability and growth of revenue is a function of the ability of the government to stimulate and sustain a high level of economic activities and an optimal mix of revenue-generating instruments. Although revenue accruing to the government over time has increased in absolute terms, their revenue profile depends largely on statutory allocations and the sharing formula while the performance of internally generated revenue has remained unsatisfactory. Ijaiya (1999) was of the view that government resources would also be allocated more efficiently if responsibility for each type of public expenditure were given to the level of government that most closely represents the beneficiaries of these outlays. Prior to the introduction of value added tax (VAT), the three tiers of government relied heavily on their share of Federation Account which in turn depended on developments in the international petroleum market regulated by OPEC. This has serious implications for government finances. Thus, government revenue had been unstable, showing up in deficits and poor delivery of services with expenditures concentrated on recurrent activities in the case of State and Local governments. This explains the use of tax contractors by some state governments and the introduction of various kinds of levies by State and Local Governments to improve their revenue. Hence advantage is taken of the country's resource endowments to enhance the revenue potential and raise the level of total federally-collected revenue with the ultimate aim of improving revenue accruable to Federal, State and Local Government through statutory allocations.

Revenue allocation in Nigeria borders on the promotion of national unity and rapid economic growth and it is however sad that despite continuous increase in revenue generation, the expected impact on economic growth in

ISSN 2632-9409

Received Jan 10, 2018 / Accepted Jun 20, 2018 / Published Jul 05, 2018 
Nigeria has not been realized. Hence the need to empirically examine the revenue allocation formula adopted in the past and its impact on the economic growth process in Nigeria. An optimal revenue allocation formula invariably leads to economic growth in the country.

\section{Literature Review}

Studies have been carried out on fiscal federalism and revenue allocation as well as the role of government in the economic growth process of a country. Woller \& Phillips (1998) could not find a robust relationship between economic growth and decentralization, using a sample of a few developing countries. However, in Nigeria, a crosssectional analysis on the expenditure responsiveness of states to federal allocation during the civilian era by Akinlo (1999), through the use of OLS technique found that the state government's fiscal expenditure was stimulated by federal grants during the period of analysis. Similarly, Aigbokhan (1999) also employed the OLS technique to investigate the fiscal decentralization on economic growth in Nigeria and finds evidence of which concentration ratio of both expenditure and revenue. It also finds evidence of mismatch in spending and taxing responsibilities with states being higher hit. Yilmaz (2000) on the impact of fiscal decentralization on macroeconomic performance for the period 1971-1990, realized that decentralization of expenditures to the local level increases the growth of real GDP per capita in unitary states more strongly than in federal states.

The impact of revenue allocation formula of individual federating units on economic growth of Nigeria is demonstrated in the study of Usman (2011), utilizing OLS technique finds that both shares of federal government and local governments' revenue from federation account contribute to economic growth process in Nigeria. The study finds no contribution of a share of states revenue from federation to economic growth process in Nigeria, which is contrary to the findings of the studies of (Akinlo; 1999; Akujuobi \& Kalu, 2009). Usman (2011) uses the growth rate of shares of the federating units from the federation account as proxies and finds a direct relationship between revenue allocations to federal, states, and local governments and economic growth process in Nigeria. Dang (2013) adopts the preliminary test of time series data, and

ECM and Pair-wise Granger Causality test to ascertain the causal relationship and the direction of causality between revenue allocations and real GDP in Nigeria. The result shows that that the lag values of all the independent variables (revenue allocations to the federal government, states, and local governments) jointly impact on RGDP of Nigeria for the period 1993 to 2012, with only revenue allocation to states showing a negative significant result. This study will also adopt the time series model and a log-linear analysis for discrete time series data, Co-integration and error correction mechanism (ECM) using E-views 8 for the analysis of the relationship between revenue allocation and the real GDP in Nigeria.

\section{Principles of Fiscal Federalism}

Fiscal Federalism in Nigeria is synonymous with revenue allocation and "resource control". There has always been controversy on the appropriate formula that should be used to divide resources in Nigeria. The concept of fiscal federalism was first introduced in Nigeria in 1946 following the formation of a federation of three regions by splitting the Southern Province into the Eastern and Western Regions, while the Northern Region which was a continuation of the Northern Province remained intact. This followed the adoption of the Richards Constitution, prior to the 1914 amalgamation of Nigeria into the Southern and Northern protectorate and the Crown Colony of Lagos into a single entity. The Nigerian federal system metamorphosed thereafter from a two-tiered federal arrangement initially comprising three unequal political and administrative regions to the current three-tiered federal system of 36 states, one Federal Capital Territory and 774 Local Governments (Ijaiya, 1999).

Every government seeks to achieve macroeconomic objectives in a particular system of government. Various systems of government include federation, unitary, and confederation. Nigeria is a federal system of government which achieves her macroeconomic objectives by performing the functions of resource allocation, income distribution/redistribution, and economic stabilization within the central government and its units (states and local governments). This is a system characterized by Fiscal Federalism. Salami (2011) contributed by stating that Fiscal Federalism is the inter-government fiscal relation as enshrined in a federal constitution, provided for the functional responsibilities to be performed by the multi-levels of government and the financial resources that can be raised for the provision of collective goods and services. Fiscal Federalism recognizes two or three levels of government in which one central government must not perform the role of the other tiers of government in economic management, thus each level of government have different expenditure responsibilities and taxing powers. In the strong central government approach, the federal government retains the larger share of revenue and the state/ local governments 
have a smaller share out of the federation account. This is known as decentralization. Sharma (2005a) clarifies that while fiscal federalism constitutes a set of guiding principles that help in designing financial relations between the national and sub-national levels of government, fiscal decentralization, on the other hand, is a process of applying such principles. However, Likita (1999) is of the view that in the decentralized approach, the federal government retains a lower share, with states and local governments having a larger share out of the federation account. Mbanefoh (1998) argues that it may be practically impossible to satisfactorily balance the financial resources of a segment of a federation with the functions which it is expected to perform. Okeke (2004) concluded that this imbalance should not be regarded as a result of federalism but as a result of the disturbances of the equilibrium which ordinarily would allow the segments of the federation to carry out developmental programs that could be undertaken with the available internal resources.

The concepts of fiscal federalism are related to vertical and horizontal fiscal relations. The notions of horizontal fiscal relations are related to regional imbalances and horizontal competition which are non-controversial whereas, the notions of vertical fiscal relations are related to vertical fiscal imbalance between two senior levels of government that is, the center and the states which are controversial. There are principles that guide fiscal federalism and sustain the overriding factors of administrative efficiency and fiscal independence with the goal aimed encouraging the devolution of more revenue-raising powers to lower levels of government to match the functions assigned to them. These principles according to Ndubuisi (1996) include:

a) Independence and Responsibility - The respective tiers of government should not only be autonomous in their resources but such resources should be enough to carry out their autonomous functions.

b) Adequacy and Elasticity - The principle of adequacy ensures that the resources of the government are adequate so that each tier of government discharges its obligation. Elasticity implies the expansion of resources in response to rapidly growing needs and responsibilities of the government concerned.

c) Administrative Economy and Efficiency - The administrative cost should be minimal and there should be no frauds and evasions in matters of finance.

d) Accountability - Every layer of government should be accountable to their respective legislature.

e) Uniformity - The financial system should be such that every government in the system should provide an adequate level of public service without resort to higher rates of taxation than other states.

f) Fiscal Access - Every state should have the authority to develop their sources of revenue within their own ambit.

The Federation Account was established by Government in order to disburse the funds to the Federal, State and Local Governments in line with the constitution and approved revenue allocation formula. This disbursement is usually done by the Federation Account Allocation Committee (FAAC) which consists of Minister of States for Finance (Chairman), Accountant General of the Federation, Commissioners of Finance of the 36 states of the federation and representatives of other institutions such as the Central Bank; NNPC; Federal Inland Revenue Service; Customs, National Pension Commission, Debt Management Office (DMO), usually on a monthly basis.

The Decree No. 49 of 1989 established the Revenue Mobilization, Allocation and Fiscal Commission (RMAFC) to oversee revenue sharing and mobilization. The RMAFC established in 1989 are constitutionally charged with the responsibility of ensuring that this disbursement exercise is accurate, fair and transparent. The constitution provides that all federal revenues must go into the Consolidated Revenue Account and this is a standard practice in most federations. In Nigeria however, an additional account is also established by the constitution, that is the Federation Account into which majority of federally raised revenues must flow with the exception of personal income tax of the personnel of the armed forces of the Federation, the Nigeria Police Force, the Ministry or department of government charged with responsibility for Foreign Affairs and the residents of the Federal Capital Territory, Abuja. This shows that fiscal federalism is all about the relationship between the different units of functions and tax powers to the constituent units. It studies how competencies (expenditure side) and fiscal instruments (revenue side) are allocated across different (vertical) layers of administration which the Government uses it to enforce National rules and standards. The concept of fiscal federalism is relevant for all kinds of government: unitary, federal and nonfederal. The existence of an imbalance between functions and resource base makes it expedient for the higher level of government to transfer revenue to the lower level. This is referred to as 'efficiency transfer or balance'. There are two primary types of transfer: Conditional and unconditional. A conditional transfer from a federal body to a province, or another territory, involves a certain set of conditions. If the lower level of government is to receive this type of transfer, it must agree to the spending instructions of the federal government. An unconditional transfer, on the other hand, is usually a cash or tax point transfer, with no spending instructions (Usman, 2011). 


\section{Nigeria's Experience on Revenue Allocation}

Revenue sharing in Nigeria has evolved significantly over the years. Revenue allocation, as it involves the federating system allocating resources to their constituent units for economic activities has been said to have a major issue in the Nigerian political system even from the pre-independence era. At any level, the whole essence of Revenue Allocation is to necessitate a just and fair revenue sharing system.

Since Nigeria gained independence in 1960, the relationship between federal government functions and the lower tiers of government have not changed significantly only for few exceptions during the military regimes. About nine fiscal commissions were appointed to examine Nigeria's revenue sharing arrangements between 1948 and 1988. These include (Phillipson, 1946; Hicks, 1952; Chick, 1954; Raisman, 1959; Binns, 1964; Dina, 1968; Aboyade, 1977; Okigbo, 1979; Danjuma, 1988; commissions, Ekpo, 2004; Jimoh, 2003).

In Nigeria's post-independence, so many fiscal review commissions were set up by different governments in order to work out an acceptable revenue allocation formula for all tiers of government. Just like other postindependence formulae on revenue allocation, the Okigbo Commission's recommendation was accompanied with controversy, disagreement, and conflict.

In recent years, the issues of resource control, revenue allocation, and fiscal federalism have dominated discussions at various levels of Nigeria's political debate. In Nigeria, revenue allocation is taken as the distribution of National Revenue among the various tiers of Government in the Federation in such a way as to reflect the structure of Fiscal Federalism. Federalism refers the existence in one country of more than one level of government, each with different expenditure responsibilities and taxing powers. The Federal Government, 36 State Governments and the 774 Local Governments have a percentage of the revenue allocated from the federation account which is distributed in the following proportions: 48.50 percent to the Federal Government, 26.72 percent to States, 20.60 percent to the Local Government councils, and 4.18 percent to centrally control special funds on the basis of the following indices and percentage weights: equal shares to each state or locality at 40 percent; population at 30 percent; social development needs at 10 percent; land mass and terrain at 10 percent and internal revenue generation at 10 percent (Suberu, 1994). Normally each tier of Government should be given adequate resources to be able to discharge its constitutional responsibilities, which is very important for the preservation of the autonomy of the constituent units. The importance of revenue generation, allocation as well as its distribution towards maintaining both the existing and new socio-political-economic structure in any economy be it centrally planned, market or mixed economies cannot be overemphasized.

\section{Principles of Revenue allocation in Nigeria}

Revenue allocation refers to the redistribution of fiscal capacity between the various levels of government, or the disposition of fiscal responsibilities between tiers of government. Revenue sharing arrangement is at two levels: One is the vertical allocation which is among federal, state and local councils, secondly is the horizontal allocation, among the states and the local governments. Revenue allocation is meant to attain two broad objectives, namely, efficiency and equity. However, the allocation formula is guided by certain allocation principles like population, equality of states, internal revenue generation, and landmass and principle of derivation. These principles according to Salami (2011) are exhaustively explained below:

Derivation principle: The principal believes that revenue in the federation account should be allocated on the basis of each state's contribution to total revenue. That is, all revenue which can be identified as having come from, or can be attributed to, a particular region or state should be allocated to it (Phillips, 1971). This principle was criticized because it makes rich states (or naturally endowed states) richer since the more endowed or developed states will contribute more to the federation account, starving the less endowed or less developed states of developmental funds. It can, therefore, leads to greater disparity among the States and subsequently lead to instability within the country.

The principle of need: The principle advocated that states are not equally endowed with resources, some states are more populated and developed than others, and therefore, more resources should be given to the less developed states to bridge the gap in development.

The principle of National Interest: The principle is based on the importance attached to developing all states to increase progress and sense of belonging. It will promote national unity by sharing the revenue in the federation account equally among States. This formula was to strike a balance between equity, and needs of national economic/ political growth leading to stability. 
The principle of Independent Revenues: This principle advocates that states can introduce or charge revenue yielding taxes within the state as long as it is a stable source of revenue but must conform to the principles of taxation within the economy and take into consideration national interest.

\section{Research Methods}

Ordinary Least Squares (OLS) shall be used for the preliminary estimation followed by Co-integration diagnostics tests and Error Correction Model (ECM) on E-views 8 for this study. Time series data from several issues of CBN Statistical Bulletin shall be used for the study covering the period $1984-2015$. The rationale for this range of period relates to the fact that the mid-1980s witnessed the structural adjustment programme (SAP) in Nigeria when interests for fiscal allocation heightened. Again, full data for 2016 were not readily available at the time if this write-up, hence, the data range stopped at 2015. The study shall carry out unit-root tests using the Augmented Dickey-Fuller (ADF) methodology for stationarity to ensure that regression results are not spurious. Thereafter, the Johansen methodology shall be used to obtain the maximum Eigenvalues and trace statistics so as to ascertain co-integration between the regressand and the regressors in the model. After this, the error correction mechanism would be carried out to determine the impact of the speed of adjustment of the model to any deviation from the equilibrium.

\section{Model Specification}

Theoretically, economic growth is influenced by diverse factors but this study shall adopt the endogenous model which stresses the importance of investment in new knowledge, research, and development in technology, capital and labor availability. Thus the expanded model of the endogenous growth model is given by:

$\mathrm{Y}=F(\mathrm{AR}, \mathrm{K}, \mathrm{L})$.

Following the assumption of Romar model, the stock results from expenditure on research and development, AR, is identified by the shares of revenue to the federal, state and local government from federation account into the model. This is because revenue enters the growth equation through expenditure on capital projects and development. Thus the model becomes:

$\mathrm{RGDP}=F(\mathrm{RALFG}, \mathrm{RALST}, \mathrm{RALG}, \mathrm{K}, \mathrm{L})$.

In addition, capital accumulation and availability of labor is influenced by the investment in public and private sectors of the economy. However, the lending interest rate to the investors will affect the overall economic growth in the country which goes to affect the amount of capital accumulated for investment purposes. This can attribute to the fact that low lending interest rate will encourage investors to loan funds from the bank and high-interest rate will discourage investment. Hence using lending interest rate which is also a determinant of economic growth to capture the availability of labor and capital accumulation, the model is then given by:

RGDP= $F$ (RALFG, RALST, RALG, LIN)

Finally, inflation rate is included to capture macroeconomic instability which has been said to be detrimental to economic growth and development in an economy. These include uncertainty about the profitability of long-term investment and a tendency toward speculative activities.

Thus the model takes the form of a single equation in economic growth as:

RGDP $=F($ RALFG, RALST, RALG, LIN, INF).

Thus converting the above model to an econometric model;

$\mathrm{RGDP}=\beta_{0}+\beta_{1} \mathrm{RALFG}_{1 \mathrm{t}}+\beta_{2} \mathrm{RALST}_{2 \mathrm{t}}+\beta_{3} \mathrm{RALG}_{3 \mathrm{t}}+\beta_{4} \mathrm{LIN}+\beta_{5} \mathrm{INF}+\mathrm{ECM}+\mu$

Applying the log-linear analysis to the model;

$\operatorname{LogRGDP}=\beta_{0}+\beta_{1} \operatorname{logRALFG}{ }_{1 \mathrm{t}}+\beta_{2} \operatorname{logRALST} \mathrm{T}_{2 \mathrm{t}}+\beta_{3} \operatorname{logRALG} \mathrm{AL}_{3 \mathrm{t}}+\beta_{4} \log \mathrm{INF}+\beta_{5} \operatorname{logLIN}+\mathrm{ECM}+$

$\mu_{\mathrm{t}} \ldots$

Where,

LogRGDP=log of Real Domestic Product;

$\operatorname{logRALFG}=\log$ of Revenue Allocation to Federal Government;

$\operatorname{logRALST}=\log$ of Revenue Allocation to State Government;

$\log$ ALG $=\log$ of Revenue Allocation to Local Government;

$\log \mathrm{INF}=\log$ of Inflation;

$\operatorname{logLIN}=\log$ of Lending Interest rate.

$\mathrm{ECM}=$ Error Correction Model

$\beta_{0}$ is a constant; $\beta_{1}, \beta_{2}, \beta_{3}, \beta_{4}$, and $\beta_{5}$ are coefficients of the regression model, 
$\mu$ is the error term (disturbance term) and $t$ is the time.

Where, $\quad \mathrm{H}_{0}=\beta_{1}, \beta_{2}, \beta_{3}, \beta 4, \beta 5=0$

$\mathrm{H}_{1}=\beta_{1}, \beta_{2}, \beta_{3}, \beta_{4}, \beta_{5} \neq 0$.

$\beta_{\mathrm{o},} \beta_{1}, \beta_{2}, \beta_{3},>0 ; \beta_{4}, \beta_{5}>$ or $<0$

\section{Findings and Discussion}

\section{Unit Root Test}

All the variables, however, became stationary after taking their first difference. This is again evident from the fact that the calculated ADF test statistic of all variables in their first difference form is greater than their respective 5 percent critical values. Since all the variables are stationary at first difference, we can affirm that they are all integrated of order one, denoted as I (1).

Table 1

Augmented dickey-fuller unit root test

\begin{tabular}{llllll}
\hline Variables & $\begin{array}{l}\text { ADF test statistics at } \\
\text { levels }\end{array}$ & $\begin{array}{l}\text { Test critical } \\
\text { value (5\%) }\end{array}$ & $\begin{array}{l}\text { ADF test statistic at } \\
\text { first Difference }\end{array}$ & $\begin{array}{l}\text { Test critical } \\
\text { value (5\%) }\end{array}$ & $\begin{array}{l}\text { Order of } \\
\text { integration }\end{array}$ \\
\hline LGDP & -0.2507 & -2.9571 & -4.0096 & -2.9604 & $\mathrm{I}(1)$ \\
LRAFG & 0.2031 & -2.9640 & -4.7494 & -2.9719 & $\mathrm{I}(1)$ \\
LRAST & 0.1404 & -2.9571 & -5.1431 & -2.9604 & $\mathrm{I}(1)$ \\
LRALG & 1.1025 & -2.9640 & -4.1572 & -2.9719 & $\mathrm{I}(1)$ \\
LCPI & -1.5745 & -2.9640 & -3.6722 & -3.5684 & $\mathrm{I}(1)$ \\
LLIN & -1.6021 & -3.5578 & -5.3564 & -2.9604 & $\mathrm{I}(1)$ \\
\hline
\end{tabular}

Source: Author's Computation using E-views 8

\section{Co-integration Test}

The result from the Johansen Co-integration test suggests the existence of a long run co-integrating relationship among the variables used in the model. This decision is reached by observing that the null hypothesis of no cointegrating equation is rejected since the values of both the Trace and Max-Eigen statistics are higher than their respective critical values at 5 percent level of significance. However, the null hypothesis of at most two cointegrating equation cannot be rejected since the values of both the corresponding Trace and Max-Eigen statistics are lower than their respective critical values at 5 percent level.

Table 2

Johansen Co-integration Test

Variables: LGDP, LRAFG, LRAST, LRALG, LCPI, LLIN

\begin{tabular}{llllll}
\hline $\begin{array}{l}\text { Hypothesized } \\
\text { No. of CE(s) }\end{array}$ & Eigen Value & Trace Statistic & $\begin{array}{l}5 \% \text { critical } \\
\text { Value }\end{array}$ & $\begin{array}{l}\text { Max-Eigen } \\
\text { statistic }\end{array}$ & $\begin{array}{l}\text { 5\% critical } \\
\text { value }\end{array}$ \\
\hline None & 0.8463 & 128.1757 & 95.7537 & 46.8248 & 40.0776 \\
At most 1 & 0.7721 & 81.3509 & 69.8189 & 36.9691 & 33.8769 \\
At most 2 & 0.5018 & 44.3818 & 47.8561 & 17.4165 & 27.5843 \\
At most 3 & 0.4573 & 26.9653 & 29.7971 & 15.2799 & 21.1316 \\
At most 4 & 0.3221 & 11.6854 & 15.4947 & 9.71970 & 14.2646 \\
At most 5 & 0.0756 & 1.96574 & 3.8415 & 1.9657 & 3.8415 \\
\hline
\end{tabular}

Both Trace and Max-Eigen statistics indicate 2 co-integrating equations at 5 percent level of significance 
Error Correction Model (ECM)

Table 3

Parsimonious Error Correction Model

Dependent Variable: LGDP

\begin{tabular}{llllll}
\hline Variable & Coefficient & Std. Error & t-Statistic & Probability & \\
\cline { 1 - 4 } Intercept & -0.0077 & 0.0394 & -0.1943 & 0.848 & \\
D(LRAFG) & 0.0013 & 0.1520 & 0.0086 & 0.9932 & \\
D(LRAST) & 0.2630 & 0.1276 & 2.06164 & 0.0532 & $\mathrm{R}^{2}=0.7519$ \\
D(LRALG) & -0.0332 & 0.1080 & -0.3072 & 0.762 & Adj. R $^{2}=0.6605$ \\
D(CPI) & 0.8280 & 0.1760 & 4.7052 & 0.0002 & F-stat. $=8.2271$ \\
D(LLIN) & 0.1176 & 0.1610 & 0.7306 & 0.4739 & Prob. F-stat. $=0.0001$ \\
D(LGDP(-1)) & 0.0822 & 0.1442 & 0.5695 & 0.5757 & D.W $=1.9411$ \\
ECM(-1) & -0.4109 & 0.1885 & -2.1797 & 0.0421 & \\
\hline
\end{tabular}

Source: Author's Computation using E-Views 8

The above result shows the existence of a positive relationship between revenue allocation to federal and state government and economic growth. Revenue allocation to local government is however shown to have a negative effect on economic growth. Inflation captured by LCPI and lending interest rate as represented by LLIN are both shown to positively contribute to economic growth. Lastly, economic growth (LGDP) is shown to be positively related to past values of itself (LGDP(-1)).

Judging by the values of the t-statistic of the explanatory variables of the model and their corresponding probabilities, it can be inferred that only revenue allocation to state government (LRAST) and consumer price index (LCPI) are statistically significant determinant of economic growth in the model at the 10 and 1 percent level of significance given that their values 0.0532 and 0.0002 respectively are less than 10 and 1 level of significance while the other variables are shown to be statistically insignificant within the model, that is, revenue allocation to federal government (LRAFG), revenue allocation to local government (LRALG), lending interest rate (LLIN) and past values of economic growth (LGDP(-1)). Hence at 1\%,5\%, $10 \%$ level of significance, the null hypothesis is rejected meaning that all the values of revenue allocation to the federal government, state government, and local government from the period of 1984 to 2015 have an impact on economic growth (GDP).

The error correction model $(\mathrm{ECM}(-1))$ appears with the appropriate negative sign and statistically significant at 5 percent level after estimation. This is in agreement with the Johansen co-integration test which showed that there was a long run relationship among the variables. Thus, the ECM will rightly act to correct any deviation of the dependent variable from its long-run equilibrium position.

The result also shows that $\mathrm{R}^{2}$ in this model and its adjusted counterpart is about 75 and 66 percent respectively. This means that about 66 percent of the variations in economic growth (LGDP) are explained by variations in the explanatory variables. This implies that the unexplained variation in the model is just about 34 percent. The value of the F-statistic which is a measure of the significance of $\mathrm{R}^{2}$ for the model is reasonably high at about 8.22 , and also statistically significant even at the 1 percent level. Based on this, we, therefore, accept the hypothesis that all slope coefficients in the model are simultaneously significantly different from zero and as such the overall model is significant in explaining the changes in economic growth (LGDP) over the sample period. Finally, the DurbinWatson statistic of about 1.94 is sufficiently close enough to the value of 2 for us to conclude that serial correlation is absent from the model.

\section{Policy Implication}

Most empirical studies are carried out to provide policy implications to policymakers. Thus for this study, the result obtained from the error correction model will be used as a guard.

The result shows that the coefficient of revenue allocation to state government has a positive effect on economic growth. A unit increase in revenue allocation to state government increases economic growth by 0.26 units. This implies that revenue allocation to state government contributes to the economic growth in Nigeria. However, the revenue allocation to federal government did not perform as expected as it shows that revenue allocation to the federal government only contributes a little to the economic growth in the country-given that they possess the lion share of the federation account. Hence policies should be made towards the minimization of the siphoning of national funds and more efforts should be geared towards embarking on those projects that will improve the standard 
of living of the citizens, that way, increasing economic growth. Conversely, the coefficient of revenue allocation to local government has a negative effect on economic growth. A unit increase in revenue allocation to local government decreases economic growth by -0.0332 units. This implies that revenue allocation to local government is non-appropriate for economic growth in Nigeria. Hence efforts should be geared towards efficient and effective utilization of funds at local levels. Thus these findings show that there is a significant relationship between revenue allocation and economic growth (RGDP) in Nigeria which therefore implies that the Null hypothesis is rejected and the hypotheses are valid comments.

Furthermore, the coefficient of the past values of GDP was correctly signed, showing that a unit increase in the past values of GDP will lead to improvement in the GDP by 0.0822 units. Also, the error correction factor from the result is correctly signed and passed the test at 5 percent level of significance given that the ECM must be negative and lie between 0 and -1 . Thus the ECM will rightly act to correct any deviation of the RGDP from its long-run equilibrium position.

\section{Summary, Recommendation and Conclusion}

\section{Summary of the Study}

This study has examined the revenue allocation in Nigeria and its implications for sustainable national development for the period 1984 to 2015. Principles of fiscal federalism, its challenges as well as the review of the past and current revenue allocation commissions were also examined. The results showed that the federal government receives the highest share of revenue from the Federation Account. Furthermore, the study attempted to explain the inherent factors affecting economic growth and its influence on the overall growth rate in Nigeria.

The result of the analysis indicates that revenue allocation contributes to economic growth in Nigeria although, in varying proportions implying that the local government contributes negatively to economic growth and federal government allocation did not yield proportionate result as expected. It also indicates that revenue allocation, inflation, lending interest rate and past values of GDP contributes to Nigeria's industrial productivity, increased investment level, higher growth, gross capital formation and efforts towards sustainable development.

\section{Recommendations}

Based on the review of past and present revenue allocation formulas and the empirical findings obtained in this study, the following recommendations have been made:

a) The current revenue allocation formula should be reviewed and each tier of government should be allocated revenue according to functions they perform. This is to ensure that the levels of government are able to carry out expenditure functions within their jurisdiction and ultimately improve the economic growth in the country. It is however recommended that the state and local government be given a higher share of the revenue given that they are seen to be closer than the citizens in terms of the basic needs needed by the citizens and most of Nigerians live in the rural areas where amenities are lacking.

b) Transparency, accountability, and efficiency on the part of all the levels of government should be enshrined to ensure that revenue allocated to specific projects are utilized appropriately, that way preventing the abandonment of projects when a new government emerges. This is with much emphasis to the federal government so as to correct the anomaly between revenue allocation to the federal government and real GDP.

c) The dependence of the local government on the states and federal government allocation has led to its inability to positively affect the economic growth in the country. This was confirmed by the empirical evidence from the results obtained. Hence the local government alongside the state government should be given autonomy and efforts should be made to boost the internal revenue accruing to the local and state governments.

d) The study also recommends that the machinery for revenue generation should be improved upon for efficiency and effectiveness to invigorate national development that trickles down to the masses.

\section{Conclusion}

Revenue allocation in Nigeria both in the pre-independence era and the post-independence era has been fraught with controversies. The federal, state and local governments want a sizeable share of the federation account. All the revenue allocation formulae have been geared towards the favor of the federal government, given that they have the 
highest share of the federation account. However, states and local government have been agitating for higher revenue shares of the federation account.

In this study, an empirical study was also carried out to determine the effect of revenue allocation to each tier of government on economic growth in Nigeria as it has been obtained that revenue allocation partially affects economic growth in the country. Other variables affecting economic growth such as inflation and lending interest rate as used in the model are said to contribute positively to economic growth hence encouraging investment in capital projects.

It is therefore evident that if revenue allocation to the federating units in the country is optimal and used efficiently for development and investment purposes, the country's economic growth will improve over time and sustained development will be achieved in Nigeria.

\section{Recommendation for Further Research}

In view of the fact the oil price volatility and exchange rate variability worsened government revenues and fiscal federalism thereby generating unprecedented shock to Nigerian economy, it is hereby recommended that further research be carried out on this subject matter with the scope of finding out the role of fiscal federalism in Nigeria and why the nation is experiencing a classic case of stagflation considering the global slide in oil price and fluctuations in naira exchange rates with other currencies

\section{Acknowledgements}

The author would like to thank the editor for their valuable time and advice. 


\section{References}

Adedeji, A. (1969). Nigeria Federal Finance: Its Development, problems and prospects. London, England: Hutchinson Educational Conference.

Adeleke S. (2011). Taxation, Revenue Allocation and Fiscal Federalism in Nigeria: Issues, Challenges and Policy Options. Economic Annals, Vol.1, No. 189, Pp. 34-45.

Adelowokan O. (2012). Human Capital Investment and Economic Growth in Nigeria: A Long-Run Path. Pakistan Journal of Social Sciences, Vol.9, Pp. 188-194.

Ahmed I. (2011). Revenue Allocation Formula in Nigeria: Issues and Challenges. A paper presented at the retreat organized for members of the Revenue Mobilization Allocation and Fiscal Commission, Uyo, Akwa-Ibom State. Pp. 3-19.

Aigbokhan B. (1999). Fiscal Federalism and Economic Growth in Nigeria, NES selected paper presented at the 1999 annual conference, Nigeria economic society, Abuja, Nigeria.

Akinjuobi, E. and Kalu, I.(2009). State Government finances and real asset investment: The Nigerian experience. African Journal of Accounting, Economics, Finance and Banking Research, Vol. 4, P. 9

Akinlo, A. (1999). A cross-sectional analysis of the expenditure responsiveness of states to federal allocations during civilian era in Nigeria. A paper presented at the 1999 annual conference of Nigerian Economic Society, P. 42

Anwar S. (2009). Fiscal Federalism: Principles and practices of Multi-order Governance London, Cambridge University Press

Bernard P. (1975). Modern Public Finance: The Study of Public Sector Economics. $3^{\text {rd }}$ Edition, London, Richard D Irwin Inc, P. 315

CBN (1996). Annual Report on Improving the Revenue Generating Capacity of the three tiers of Government, $31^{\text {st }}$ December, Box 4.1 Pp. 71-73

Dang D. Y.(2013). Revenue Allocation and Economic Development: An Empirical Study. SAGE, P. 2

Domar, E. (1957). Essays in the theory of economic growth, New York, NY: Oxford University Press.

Ekpo H. (2004). Intergovernmental Fiscal Relations: The Nigerian Experience. Paper presented at the $10^{\text {th }}$ year Anniversary of the Financial and Fiscal Commission of South Africa. Cape Town, South Africa. August 10-12.

Friedman J. (1972). Growth Centres in Regional Economic Development,(ed.), N.M Hansen.

Ijaiya, G. (1999). Fiscal Federalism and National Development: A framework for policy analysis. Journal of social sciences and Administration, Vol. 1 No.2 Pp. 78-85

Iyoha M. (2004). Applied Econometrics, $2^{\text {nd }}$ Edition. Nigeria: MINDEX publishing House. Pp. 48-80

Jimoh, A. (2003). Fiscal Policy and Growth in Africa: Fiscal Federalism, Decentralization and incidence of taxation. Paper presented at the Ad-Hoc Expert Group meeting- Economic Commission for Africa, UNCC, Addis, Ababa, Ethiopia. P. 26

Jinghan M. (2005). Economics of Development and Planning, 38 ${ }^{\text {th }}$ Edition Delhi:VRINDA Publications Ltd. Pp. 22, 39, 217, 229,292.

Likita, O. (1999). Elements of Public Finance, Lagos, Abayomi Industrial Packaging Ltd.

Lukpata, V. (2013). Revenue Allocation Formula in Nigeria: A continuous search. Journal of Public Administration and Management Research Vol. 2, Pp. 32-36

Matrinez-Vazquez, J. \& McNab, R.M. (2002). Cross country Evidence on the relationship between Fiscal Decentralization, Inflation and Growth in National Tax Association (ed.), Proceedings of the $94^{\text {th }}$ Annual Conference on Taxation 2001, Washington D.C Pp.42-47

Mbanefoh, G. F. \& Egwalkhide F.O (1998). Revenue Allocation in Nigeria: Derivation Principle Revisited in Amuwo, K. Agbaje A.A.B, Suberu R.T and Herault, G. Federalism and Political Restructuring in Nigeria. Ibadan: Spectrum Book Ltd. Pp. 213-231

Musgrave, R., \& Musgrave, P. (2004): Public finance in theory and practice (5th edition). New Delhi, India: Tata McGraw-Hill Education Private Limited. P. 262

Ndubuisi, W.C (1996). Practice of Federal Finance: The Nigerian Dimension, Aba Walcom Services Northern Coalition for the protection of Democracy (NCPD)(2002), A communiqué issued at the Conference on Resource control and Supreme Court verdict.

Nwabueze, B.O (1983). Federalism in Nigeria under presidential constitution, London, Sweet and Maxwell Associates

Oates, W. (1999). Fiscal Federalism, Harcourt Brace Jovanovich, Inc. Princeton University Press, P. 13

Ojo, J. (2014): An X-ray of inter-governmental relation conflicts and resource control in the fourth republic in Nigeria. Academic Journal, Vol. 6, No. 3, Pp. 43-52 
Okeke, C.C.S. (2004). Nigeria's Fiscal Relations in the 20th Century: an Inquiry into Local Government Fiscal Activities, in: Garba, A.G, F. Egwaiknide and A. Adenikinju (edited), Leading Issues in Macroeconomic Management and Development, Ibadan, Nigeria, Nigeria Economic Society. P. 42

Olofin, S., Olubusoye, O. E., Bello, A. J., Salisu, A. A., \& Olalekan, A. S. (2012). Fiscal federalism in Nigeria: A cluster analysis of revenue allocation to states and local government areas, 1999- 2008. CBN Journal of Applied Statistics, Vol. 3, No. 1, Pp. 72-83.

Omer, A. M. (2017). Identifying, Developing, and Moving Sustainable Communities through Application of Bioenergy for Energy or Materials: Future Perspective through Energy Efficiency. International Journal of Life Sciences (IJLS), 1(1), 9-39.

Omer, A. M. (2017). Identifying, Developing, and Moving Sustainable Communities through Application of Bioenergy for Energy or Materials: Future Perspective through Energy Efficiency. International Journal of Life Sciences (IJLS), 1(1), 9-39.

Omer, A. M. (2017). Sustainable Development and Environmentally Friendly Energy Systems. International Journal of Physical Sciences and Engineering (IJPSE), 1(1), 1-39. P. 34

Pérez, Antonio Vázquez, María Rodríguez Gámez, Vicente Félix Véliz Briones, Carlos Gustavo Villacreses Viteri, and Lucio Alfredo Valarezo Molina. "Sustainable Development Seen from Environmental Training in University Linkage." International Journal of Life Sciences (IJLS) 2, no. 1 (2018): 12-20.

Phillips, A. (1971). Nigeria's Federal financial Experience. The Journal of Modern African Studies Vol. 9, No.3. Pp. 389-408

Prest, A. (1972): Public Finance in Underdeveloped countries. Redwood Press Limited, Trowbridge, Wiltshire. Pp. 14-16

Romer, P. (1994). Origins of endogenous growth Journal of Economic Perspectives, Vol. 8, P. 3-22.

Sharma C. K. (2005a). When does decentralization deliver? The Dilemma of design,

Solow, R. (1956). A contribution to the theory of economic growth, Quarterly Journal of Economics, Vol. 70, Pp. 65-94

South Asian Journal of Socio-political Studies. Vol. 6, No1 Pp. 38-45

Stephen, N. \& Osagie, E. (1985). A textbook of economics for West African students, Ibadan, Nigeria University Press Limited.

Suberu, R.T (1994). Recent Demands for new States in Nigeria. Nigerian Journal of Federalism

Usman O. (2011a). Revenue allocation formula and its impact on economic growth process in Nigeria. Journal of Economics and sustainable Development Vol.2, No.3, Pp. 16, 29-37

Usman O. (2011b): Fiscal Federalism and Economic growth process in Nigeria. European Journal of Business and Management, Vol. 3, No. 4, Pp. 1-3 Vol. 2, Pp. 67-82

Woller, G.M \& Phillips K. (1998). Fiscal Decentralization and LDC Economic Growth: an Empirical investigation. Journal of Development studies 55 Pp.139-148

Yilmaz, S. (2000). The impact of Fiscal Decentralization on Macroeconomic Performance in: National Tax Association (ed.), Proceedings of the $92^{\text {nd }}$ Annual Conference on Taxation 1999, Washington, D.C, Pp. 251-260 